\title{
Cultivating the Glocal Garden
}

Matthijs Hisschemöller

Dutch Research Institute for Transitions (DRIFT), Erasmus University Rotterdam, Rotterdam, The Netherlands.

E-Mail: hisschemoller@drift.eur.nl; Tel.: +31 104088775

Submitted: 23 February 2016 | In revised form: 9 June 2016 | Accepted: 10 June 2016 |

Published: 18 July 2016

\begin{abstract}
This paper addresses the question under which conditions small-scale urban agriculture (UA) initiatives can accelerate a sustainability transition of the global food system. It develops the notion of a glocal garden, a large number of likeminded local initiatives with a global impact and forms of worldwide collaboration. Taking a transition perspective, the glocal garden, producing vegetables and fruits, is a niche that has to overcome barriers to compete with the dominant food regime. Since a sustainability transition restructures (policy) sectors, institutional domains including knowledge systems, the paper explores which innovations are needed for the glocal garden to succeed. It discusses the glocal garden as an environmental, a social, an economic and a global project. As an environmental project, the glocal garden will link sustainable production of food with renewable energy production. As a social project, it will be organized into a consumers' cooperative. As an economic project, it will strive for profit, increasing the yield in a sustainable manner. As a global project, it will enhance collaboration between local cooperatives in the North and the South, as well as with rural agriculture. Under these conditions, the glocal garden can develop into a power, able to resist a possible future food regime that splits societies, in terms of quality standards and food products, into haves and have-nots.
\end{abstract}

Keywords: cooperative; global food system; sustainability transition; urban agriculture

\section{The Question}

Small scale sustainability movements, including the widespread initiatives for urban agriculture (UA), are considered part of a sustainability transition. One feature of sustainability transitions is that current large scale activities, i.e. the production facilities, as well as transnational ownership of production and trade, become challenged by activities at a much smaller scale. This raises the question as to whether a sustainability transition of (part of) the global food system can be accelerated by increasing the share of UA. This question does not imply that, eventually, UA would entirely replace (large scale) rural agriculture. It does imply that two main features of UA, i.e. small scale gardening and substantial involvement and ownership by the (nearby) community who uses the products of the garden, can trigger an acceleration of a sustainability transition of the current food system.

Asking this question is far from self evident, if only because quite some experts would reject the idea as an idealistic fantasy. As former head of FAO Louise Fresco argues, no matter how appealing it might seem to go back to small scale, farmers markets, traditional setting and good food, it is a fallacy that comes from a past that we have forgotten about [1]. Rabbinge [2] claims that, through technical progress over the last millennium, humankind has managed to avoid the Malthusian scenario as it can continue to do in the near future. The increasing world population, from 6.1 billion in 2000 to 8.9 billion in 2050 [3], can, as Rabbinge explains, easily be fed using less land. In his view, 
a decrease of agricultural land would mean a decrease of fertilizer and pesticides use, which is a contribution to sustainable agriculture. From his perspective, a sustainable agriculture will only be possible with industry producing machines, fertilizers and pesticides [2,4]. Fresco shares this view: "Even if a decreasing number of people acknowledge it today, the application of agricultural and food system science has been one of the great success stories of mankind, and it has been such a success story because of the collective capacity of humankind to adjust to the lessons learnt [5]". In all, since the 1960 s, world population has doubled while the available calories per head increased by $25 \%$ $[5,6]$. The challenge, however, is to double food production in the decades to come, an increasing part of which for over 3 billion people already living in metropolitan areas. In her view, this is neither going to happen through farmers markets nor by relegating millions of farmers, especially in industrializing countries, into poverty. Instead, Fresco argues, people need affordable and safe food, which requires "smart" mechanization to compensate for the growing migration from rural to urban areas and to improve the labor conditions of those still working in agriculture [1].

Also from the perspective of community gardeners, exploring the potential of UA to challenge the food system is not necessarily relevant. In North-America and Europe, people participating in UA do so with a variety of motives [7-10]. As Veen [10] finds for the Netherlands, many people like to garden because they enjoy the act of gardening and not because they want to change the world or oppose the conventional food system. Findings with respect to actual motives for engaging in a social movement, however, have little bearing on the relevance of the question of the movement's potential for system change. After all, the system impact of peoples' actions is not always explained by their motives or intentions.

Overall, the urgency of a sustainability transition of the global food system is broadly recognized. However, different views exist with respect to the main issues the transition needs to address and its desired direction and goals, even including the very meaning of the concept 'sustainability' itself. Interestingly, UA has always been a worldwide phenomenon. This paper considers urban agriculture in line with the FAO [11] as the growing of plants and the raising of animals within and around cities. However, to distinguish from private (back)yards, urban agriculture produces some kind of utility or value shared within a community rather than hedonic pleasure for the private garden owner only. The value can relate to (substituted) money value, such as from vegetable crops, food security, seed saving, health, social coherence, the shared pleasure of gardening, the aesthetics of landscape etc. Therefore, it plays a role in addressing a variety of issues related to food system transition and can be part of diverging sustainability scenarios, even if environmental impacts are not under all conditions found to be positive [12]. Many point to the persistent problems in the South, such as local famines, food scarcity and natural disasters, which are expected to be aggravated by global warming and extreme weather events. Hence, for industrializing countries UA is being discussed as an option satisfying the need for food security $[11,13]$. Since the 1960s, food security is not the first priority anymore in Europe and North America. Here, community gardening is practiced under conditions of food abundance and relative wealthwith an exception for the so-called 'food deserts' in US metropolitan areas [14]. For people in industrialized countries, priority issues addressed by UA relate to the large scale polluting production facilities, the exorbitant power of the retail sector, monopolies in seed breeding and the disconnectedness between producers and users.

This paper takes into consideration the wide variety of UA initiatives, including community gardens, market gardens, (rooftop) greenhouses and other forms, as well as the variety of forms of social organization practiced. Yet, its focus is to identify and explore under which conditions UA can accelerate a sustainability transition of the food system worldwide, thereby overcoming allegedly opposed interests between the North and the South. The paper develops the notion of the 'glocal' garden, where 'glocal' refers to a large number of likeminded local initiatives with a global impact and forms of worldwide collaboration. Starting point is a small-scale initiative with large involvement and some form of ownership by the local end-users, who are primary users of the yield. The glocal garden that unfolds is in many respects similar to many UA projects, but it is primarily an ideal type1: what makes it relevant is its supposed ability to overcome institutional barriers for environmental, social, economic and global sustainability. Institutional barriers are usually defined as rules of the game that shape the behavior of actors. Rules can be formal (like laws and regulations) but also, sometimes more importantly, informal, like the kinds of knowledge and values that actors-being companies, organizations or just persons -internalize as to determine their courses of action in interaction with others. So, the glocal garden that this paper anticipates has developed institutions of its own that allow it to survive and strengthen its position vis-á-vis the food system [15].

In order to keep the paper's scope within reasonable limits, the glocal garden in this paper produces vegetables and fruits, thereby serving only part of food demand. Meat, meat consumption behavior and large scale production of animal feed, although core issues of concern as regards the sustainability of the food system, are not addressed. This is not meant to imply that the paper would be irrelevant for the food system at large.

The paper's argument is built up as follows: Section 2 discusses the dialectics of sustainability transitions, elaborating the concept of a (global) food system as the dominant regime and the glocal garden as the niche. Sections 3, 4 and 5 envision the glocal garden as an environmental, a social and an economic project, respectively. Section 6 discusses opportunities for glocal gardens to become a really global project. Section 7 summarizes and concludes. 


\section{Sustainability Transition Dialectics}

Transition theory is about system transformation, i.e. a change in social domains reflected in technology, economy and institutions [16-20]. A transition is defined as the shift from a relative stable (sub)system (dynamic equilibrium) through a period of relatively rapid change in which the system reorganizes irreversibly into a new (relatively stable) system again [21]. Transitions are supposed to take a long time frame (25 years or more), in which slow and rapid developments take turns. The outcome of a transition, i.e. how a sustainable food system will look, is uncertain, as actors involved learn during the process. A transition is always an interplay between multiple actors operating at three levels. The landscape level is relatively autonomous: developments at this level, such as international trade agreements, natural disasters, economic crises etc. trigger changes in the food system. The food system is featured by a regime, which is defined by the dominant institutions and the powers that be. At the niche level, activities and actors emerge, which are in one way or another opposed to the regime and may benefit from destabilizing developments at landscape level.

The regime this paper addresses is the worldwide food system, which includes all actors who are in some way involved in the production, (global) trade, retail and sales of food and feed. As Friedmann [22] points out, a global food regime first emerged as an international wheat regime in the 19th century. This regime, built on the idea of 'free trade', collapsed during the 1930s depression. Following World War 2, a regime emerged, which Friedmann labels the Mercantile-Industrial food regime. This regime was based on subsidies, import restrictions and, where developing countries are concerned, on subsidized exports or 'aid'. This regime began to show cracks during the 1070 s because of the rivalry between European and American food exports and the failure of the 'green revolution' in Africa.
Friedmann speculates about the direction of what could be labeled as an emerging Corporate-Environmental food regime. Drawing on Lang and Heasman [23] she identifies two competing paradigms. One anticipates a continuation of the industrial regime using advanced science for large manufacturing of (new) food products. The other builds on small scale ecological production. One salient feature of the food regime in the neo-liberal era is the increased power of the retail sector in setting food quality standards beyond those prescribed by public agencies, a trend largely encouraged by the policy catastrophe in the UK around the BSE scare in the 1990s, when supermarkets started to guarantee the safety of beef, while British government was paralyzed [24]. Friedmann notices that these standard levels (will) have an immediate impact on the diet offered to the higher and lower income groups.

$\mathrm{UA}$, in its broad variety of forms [12] is the typical niche in the food system. Niches struggle in order to become (part of the) regime, which means that behavior, technology, infrastructure and institutions at large will have to change in favor of the niche(s). Not surprisingly, niches are opposite to regimes in that they are not (yet) institutionalized, whereas regimes by definition are. However, niches are not opposing the regime in all respects and they may also be as different among themselves as they are from the regime [25]. To illustrate, organic farming contrasts the food regime as regards principles and methods of farming, but it is not necessarily different where sales and business model are concerned. An urban farm is probably very different where the relationship with its clientele (local community) is concerned. Also in terms of business model, an urban farm is different from a conventional rural farm.

Taking a system perspective, Table 1 presents an overview of the different dialectics between regime and niches in the food system transition. The left column presents the current unsustainable situation as perceived from a niche perspective. The right column presents the alternatives from a niche perspective.

Table 1. Transition dialectics in framing the food system from a niche perspective.

\begin{tabular}{ll}
\hline Regime & Niche \\
\hline Polluting & Clean \\
Negative impact on landscape & Positive impact on landscape \\
Industrial: no relation with nature & Ecological: focus on relation with nature \\
Large scale; gap between investor, producer and consumer & Small scale: knowing people, social interaction \\
Lock-in technologies in context of large scale business model & Sustainable technologies \\
Specialization, patents & Open access \\
Owned by a few & Owned by many \\
Consumer money goes far away & Money stays in the community \\
Fast food & Slow Food \\
Uniformity & Variety (forgotten vegetables) \\
\hline
\end{tabular}


Furthermore, a transition is featured by the involvement of multiple actors including governmental and nongovernmental agencies in multi-domains (interactions between related but institutionally separated fields like agriculture, nature and water) and multiple disciplines. For a good understanding of the far reaching impact of system change for the food system, it is critical to focus on the interaction between different domains. A sustainability transition has to overcome physical and social cleavages that are reproduced in current unsustainable practices and, in a sense, help in reproducing these. It may be hard to imagine, but in the 'end' domains or separate systems that are currently taken as self-evident may have ceased to exist or have become articulated in a completely new way. In the context of the perspectives for UA we may think of the following cleavages to be overcome:

- the urban and the rural. In many places in the world, including large metropolitan areas, it has become difficult to point to boundaries between the urban and the rural; hence, researchers into urban landscape management have introduced the term urban-rural continuum [26];

- food, energy, waste, water and soil may become integrated in (a) new (sub)system(s);

- the distinction between knowledge production and knowledge application, scientific and practical knowledge may become obsolete;

- the current neoliberal economy treats consumers as passive (even if advertisements suggest otherwise); however, in a sustainability transition consumers are becoming producers of energy and food, which has led to the introduction of the term prosumers;

- private and public ownership, the distinction between market sector and public sector may vanish as consumers organize themselves in cooperative enterprises such as urban farms.

As today's physical and conceptual cleavages are part of commonsense thinking and of social institutions including policy agencies, (international) agreements and laws, science disciplines and even common language, changing these does not go overnight and will meet with considerable hardship. At the same time, it would open major opportunities, many of which we cannot imagine today. The next sections will unfold in more detail how reshaping domain demarcations helps in envisioning a glocal garden that fulfills ecological, social and economic needs.

\section{The Glocal Garden as an Environmental Project}

Unless agricultural land is used for industrial agriculture or mono-crops that hinder biodiversity, peri-urban landscape is enjoyed by many for recreational and health purposes. Functions, such as protection of biodiversity and small-scale recreation, can, at least in many European countries where subsidies are available, add to the farmers' income. For UA these functions are obvious, especially the landscape aspects of a garden in a vibrant city. This means that UA as an environmental project will abstain from the use of agro-chemicals and will try to minimize energy and water consumption. However, there is more to say about the glocal garden as an environmental project.

An important synergy for agriculture in an urban context is the production of renewable energy. This is especially important in countries that suffer from regular electricity fall-outs. For cities and towns with a moderate climate, which have a large demand for heat, the concept of the 'greenhouse village' is interesting. For areas with a warm climate, but with large temperature differences between day and night or another natural cooling source available (the sea), the notion underlying the greenhouse village concept may serve for sustainable cooling. This concept [27] links agricultural production in greenhouses to the demand for heat in households. During summer, a greenhouse receives far more heat from the sun than it needs over the year. The excess heat can be harvested and stored in underground aquifers to be used in winter (aquifer thermal energy storage -ATES). The surplus can be delivered to the nearby neighborhood. Through digestion of black water from households' toilets, kitchen waste and biowaste from the greenhouse in an anaerobic high pressure digester adjacent to the greenhouse, gas is produced [28]. This can be used for power generation (electricity) and tap water heating. The remaining $\mathrm{CO}_{2}$ and the waste water can be reused as fertilizer in the greenhouse.

This cradle to cradle option has not been realized in practice, but it offers future possibilities, as also recognized by Fresco ([5], p. 381). One of the implementation problems is that it challenges the dominant knowledge framework as regards energy saving and heat provision and gives rise to knowledge conflict [29]. The option supposes a radical shift in heating from the 'normal' way, with heat distribution systems that handle so-called low value heat (up to $90^{\circ} \mathrm{C}$ ), to a system that provides Very Low Value Heat (about $35^{\circ} \mathrm{C}$ ). Distributing systems for very low temperature heating (or high temperature cooling) find their way to the market slowly, meeting with resistance, where natural gas is the common heat source. The example of the Greenhouse Village is powerful as it shows how energy and food production can be combined though technologies that are not very complex and accessible for SMEs.

A second option that illustrates a possibility of integrating food and energy is known under the name 'Terra Preta' or Very Black Earth. This earth has been found in Amazonia and parts of Western Africa and goes back to 2500 $\mathrm{BC}$. The native farmers have improved the soil by regularly adding charcoal to it [30]. Charcoal is produced from locally available biomass. Through pyrolysis (combustion without oxygen at relatively low temperatures) the biomass is split in an oil (or gas) and a carbon fraction. Storing the carbon underground enriches the soil and increases the harvest. Another advantage for local farmers is that the oily fraction can be used for electricity generation at local level. This offers a local energy solution for (remote) areas not connected to a (vulnerable) grid. These qualities 
make underground carbon storage a much better idea for addressing $\mathrm{CO}_{2}$ emissions than underground storage of $\mathrm{CO}_{2}$ [31]. For industrializing countries in particular, this option might provide communities with energy as well as additional income [32]. Since the carbon stored is provided by biomass instead of fossil fuels, this option has the potential of leading to a negative carbon balance. Since it is cheaper than $\mathrm{CO}_{2}$ storage [32], transnational energy companies could benefit if they transfer carbon credits to UA cooperatives in developing countries [33].

The Terra Preta option illustrates that for UA boundaries between expert knowledge and knowledge in practice, between knowledge production and application become blurred. The knowledge on Terra Preta existed long before academic knowledge became standard [34]. Knowledge on the benefits of carbon storage spread over the world since humankind started with agriculture in an era when physical distances could not be overcome with modern means of communication. Still, hobby gardeners all over the world know that carbon may improve the soil, although it is uncertain if this works for every soil type.

In conclusion, this section illustrates that the glocal garden can benefit from innovations that produce synergies between the urban and the rural, between agriculture, energy, waste, water and soil and that this is good for the environment. Another issue is that such synergies are beneficial for the finances that the urban farmers may need to provide their enterprise with a stable economic prospect.

\section{The Glocal Garden as a Social Project}

The main barrier for the glocal garden as a social project has been identified by Hardin [35] as the Tragedy of the Commons. The metaphor is the common pasture that in the end will suffer from overgrazing, as the farmers will do their best to get all benefits from the common land and will not invest in its maintenance. Drawing on this metaphor, modern people will do their own thing first and neglect or postpone their obligations as regards the community garden. Olson [36] had already referred to this phenomenon as the 'logic of collective action'. The main argument is that a rational individual will take a free ride when it comes to realizing or protecting a public good, i.e. a good that is accessible to all and from which no-one can be excluded (clean air, landscape view, peace etc.). The main driver for rational individual behaviour is not, as is often assumed, selfishness, but in Olson's words, that a person's individual contribution would not be perceptible ([36], p. 64). Olson argues that rational individuals want to contribute to a public good under two conditions only: (1) when there is coercion (government regulation and enforcement) or (2) when those who participate are provided with selective benefits.

Modern policy analysts argue that theories and metaphors like the logic of collective action and the tragedy of the commons are outdated. New institutionalists, like Ostrom [37], have shown that groups are perfectly able to enforce mutual agreement on sustainable behaviour, such as fishermen protecting their fish stock. There are many examples of successful collective action, including citizens cooperatives for UA, which suggest that Olson and allies were wrong. Before jumping to conclusions on the social conditions for a glocal garden four issues need careful attention: (1) group size, (2) the degree of consensus on the values associated with selective benefits and (3) empowerment, control and trust.

\subsection{Group Size and Social Cohesion}

According to Olson's theory people are expected not to voluntarily protect public goods, especially if the public good relates to the interest of the largest possible group. In contrast, small groups are much more likely to succeed in promoting their interests. The large majority with an interest in peace is less well organized than the small group that at times has an interest in war ([36], p. 166). Therefore, the large group not only provides evidence for Olson's thesis, "they also suffer if it is true" ([36], p. 167).

The idea that small groups are more effective in promoting their interests than large groups can also be found in the literature on the so-called Not-In-My-Back-Yard (NIMBY) syndrom [38,39], which explains local opposition in case of locally unwanted land uses (LULUs). Unwanted land uses benefit the large group, including people living far away, whereas the costs (burdens) are for the local community in their immediate vicinity. Hence, the per capita costs motivating people to resist the LULU are much higher than the per capita benefits that motivate people to realize it. This explains why NIBVMY resistance is often successful [40]. The remedy proposed is to provide locals with selective benefits, i.e. compensation or even reward, in exchange for acceptance. This approach is supposed to lose effectiveness, once values are at stake that cannot, according to those involved, be framed in monetary terms, such as health and safety.

So, the logic of collective action and concepts similar in that they are all based on economic rationality, support the idea that small groups are in a fairly good position to realize and maintain a public good, like a community garden, whereas a large group would probably fail. An (implicit) assumption behind the logic of collective action is that people act in social isolation, like in the prisoner's dilemma [41]. In reality, however, individuals act in accordance with their personal level of attachment to social norms [42]. This is especially the case for small groups, where people are likely to know each other and where social control may serve as an incentive for engagement.

\subsection{Degree of Consensus on the Values Associated with Selective Benefits}

Yet another factor relevant for both success and failure of the glocal garden as a social project relates to the different types of selective benefits offered to the people involved. Many of these are in kind, like vegetables and flowers from 
the garden, but also of a non-material nature. Many urban farms started as community projects such as after school programs or educational centers for inner-city kids. People might very well experience the act of gardening or the opportunity to establish friendly relationships with others via the community garden as social benefits. Several students of community projects find that the need for social cohesion is a very important driver for people to engage [43].

However, the social act of gardening together with neighbours, which according to many makes a strong case for UA in a local community context, may also signify its vulnerability. After all, many people don't like gardening, many even dislike it, as it is at times dirty and very hard work. People may simply want to spend their time in a different way, for example, undertaking activities with their families and friends. Many would not care so much about the new social relationships offered, as they already lack the time to maintain their current ones. They may take care of their own garden or allotment garden first, before spending time in the community garden. Hence, there is reason to believe that these people, probably a large majority, are unlikely to either engage in an urban farming project or to persevere with their contribution in the long run. This has to do with the observation that the values at stake with a public good, like an urban farming project, are not the same for everyone ([36], p. 60). Dissent on the values related to the public good in everyday life undermines the glocal garden as a social project.

\subsection{Empowerment, Control and Trust}

A different type of benefits relates to the empowerment of people who experience lack of control in a world food system featured by huge distances, social as well as physical, between producers, wholesale, retail, investors and consumers. Consumers of food may (re)gain control over (part of) their food through a local cooperative, an inclusive local enterprise.

Agriculture cooperatives are not at all a new phenomenon. In the late 19th century, several countries witnessed initiatives to form producer cooperatives with the aim of getting a fair price for vegetables, flowers and fruits through local auctions. Auctions replaced the by then intransparant networks through which vegetables and fruits were brought to the (consumer) markets [44,45]. According to Tourte and Gaskell [46] the Netherlands in particular faced a spectacular number of cooperative auctions. Although the economic reasons for agriculture cooperatives were quite compelling, there were many obstacles to overcome. Auctions suffered from their members' unwillingness to bring their apples and pears to the auction [47]. The real breakthrough came in 1916, when the Dutch government ruled that vegetables and fruits had to go through an auction, preventing exports of Dutch produce to countries involved in the war, where demand for fresh products was high. When government coercion was lifted after the war, fruit growers in several provinces turned back to the old practice. Tourte and Gaskell [46] refer to other examples of hesitations to volun- tarily offer products to the auction and the decisive impact of state intervention in the Netherlands and Japan. In countries like the United States, cooperatives appear to have been more effective without state intervention. However, as Tourte and Gaskell [46] state, the history of producer cooperatives has not been very well documented.

The case of cooperative auctions shows a nice example of a prisoner's dilemma or tragedy of the commons, even among relatively small local groups. In spite of a joint interest in advancing their sales through cooperative auctions, producers showed lack of trust in the new institution. Quite a number of social theories would lead to conclude that especially small, informal, homogeneous groups are effective in building trust, as these are able to reinforce normative sanctions $[48,49]$. However, there is no evidence that local initiatives for urban farming are a panacea for lack of trust. To the contrary, people who know each other personally may also know whom to trust or not.

Still, the UA cooperative, where consumers enact control over the production of their food, is to be considered a major institutional innovation. What is new is that the enterprise is owned by consumers rather than producers, that consumers become investors and share in the eventual profits of the undertaking. Being a legal entity, a cooperative can also work on building relationships of trust in the community by explicit and transparent rules of the game that can be controlled by its membership (cf. [37]). According to Tilly, who has contributed much to the foundation of resource mobilization theory, political rights and political opportunity rather than prospects for financial gain help a social movement to gain momentum. Interestingly, Tilly [50] found this a decisive element in a comparative case study on food riots in the medieval era and early modernity. The major relevance of the UA cooperative is not so much that it is an enterprise, but that it may become a vehicle to reduce distances between producers, consumers and investors and, as such, contribute to a different (circular kind of) economy [51].

To conclude, with respect to the glocal garden as a social project, its main challenge to overcome is the tragedy of the commons; many like the idea of urban farming but most do not sufficiently contribute to make it happen or to keep it going. Indeed, the project must be local and small-scale as to enable for sufficient social benefits. A cooperative enterprise is essential for the glocal garden as a social project, because, next to a variety of (material and non-material) benefits, it provides empowerment and control.

\section{The Glocal Garden as an Economic Project}

To address the economics of the glocal garden touches upon a sensitive issue. Many community projects related to UA are buttressed by volunteers and are not aimed at making profit. There are also internationally operating, profit seeking companies who specialize in (high tech) UA, but have little or no connection with local communities. There is a belief among scholars of social innovation and sustainable 
business models that sustainable enterprise is-and perhaps should be-primarily interested in generating ecological and social values and in last instance only a 'moderate' profit at most $[52,53]$. Without having any problems with voluntary community projects, economic viability becomes an issue once the glocal garden is to become a challenge for the worldwide food regime. The garden needs protection, if only against urban land owners, developers and planners who may want to arrange for new activities on the garden land. The garden may need money to buy the land in order to safeguard it for future speculations by the land owner and local government. There are many more reasons for an UA project to make a profit. Perhaps more importantly, there is no compelling reason to deny a sustainable enterprise the right of making a profit.

Whereas the glocal garden must remain relatively small in order to meet its social challenges, from the point of view of economics this does not look like a reasonable request. After all, the global trend in agriculture, including the production of vegetables and fruits, is towards large scale farming, higher efficiency, producing more with less people and less space. Hence, the major challenge from an economic point of view is to remain small and, at the same time, realize some economic (financial) benefits. There is reason to believe that this is very well possible.

Firstly, economic prospects relate to the way local involvement and ownership areorganized. When the consumers are simultaneously investors in the cooperative, their money stays in the local community. For a sustainability project such as UA, consumers are willing to accept a margin much lower than a professional investment company or bank.

Second, an end user cooperative with a local base can afford to offer the products to customers without intervention from wholesale or retail. This saves a lot of money. Van der Noll et al. ([54], p. iii) distinguish the following breakdown costs in the Dutch consumer price: (1) price for producer, (2) retail (package, logistics, transport and storage), (3) gross margin supermarket and (4) VAT. The breakdown is given for a typical Dutch product, the greenhouse paprika. For each euro received by the producer in a specific week the consumer paid $€ 2.63$ in the supermarket, i.e. a difference of over $60 \%$. Without arguing about the average figures it would not be unreasonable to assume price differences over $50 \%$. Since the (European) retail sector has producer contracts all over the world, the prices paid to small producers in eg. Kenya are probably not higher than those paid to Dutch producers. Up scaling in professional horticulture is to a large extent caused by the pressure on the farmer to raise efficiency and production, as buyer competition in the market has dropped under the growing power of an oligopolistic retail sector [22]. According to a leader of a Dutch farmers union, this trend is causing the collapse of the food system [55]. Avoiding wholesale and retail will not only lead to cost savings for the benefit of the cooperative, it is also an important disincentive to go for large scale farming.

Third: when it comes to costs and benefits, another issue is as to whether a small garden (even a few hundred square meter) can realize an economically acceptable amount of produce, especially if the garden wants to avoid the use of pesticides. It may be no surprise that estimations vary considerably, but many are quite optimistic. According to FAO [11], garden plots can be up to 15 times more productive than rural holdings. An area of just one square meter can provide $20 \mathrm{~kg}$ of food a year. Especially for industrializing countries, the potential of UA for food security appears beyond dispute [56]. Also for industrialized countries there are optimistic reports. Japanese UA is more productive than its rural counterparts. According to government 2010 data, urban fields are the most productive kind of agriculture in terms of economic value of production per area-3\% more productive than the national average [57]. An estimate for London [58] assumes a productivity level of over $10 \mathrm{~kg}$ per $\mathrm{m}^{2}$. Bellows, Brown and Smit [59] state that a 100 $\mathrm{m}^{2}$ garden in a temperate 130 days growing season can produce most of a household's vegetable needs, including the nutritional requirements for vitamin $\mathrm{A}, \mathrm{B}$ and $\mathrm{C}$ complex and iron. However, in so far as actual output is concerned, much lower figures are reported for the USA [60].

All in all, these figures are not conclusive, but what adds to the optimism is the trend, especially in North America, of small-scale commercial urban farming among young entrepreneurs [60]. A well-known example is Le Jardin de la Grelinette in St Armand, Quebec, Canada. The farmer, Fortier [61] describes in some detail how he manages to do intensive organic farming on a piece of ca 1 ha and make a living out of it. One important way to increase efficiency has been the development of tools that apply to small-scale farming. Another important strategy, found among urban farming projects to raise financial output is to diversify their produce. Urban farms can grow several varieties of one kind, with different shapes, forms and colors, including socalled 'forgotten' vegetables and fruits. Many of these are not available in the regular food store but they are attractive for customers interested in good food. For the near future, linking urban food production with the production of energy may also add to the economic prospects of the glocal garden.

An additional positive effect of the glocal garden, run as a for-profit company, would be its contribution to employment. Worldwide, small and medium sized companies (SME) are estimated to give a major contribution to GNP, about 60$70 \%$ [59]. Although wages might not be exorbitant, concern with respect to labor conditions in agriculture may not apply for the glocal garden, since many of the personnel will probably be co-owning the enterprise. According to ILO ([62], p. 25), job satisfaction tends to be higher for employees of SMEs. This may be related to factors such as greater work autonomy and a lower degree of division of labor.

\section{The Glocal Garden as a Global Project}

Realizing an impressive yield/ha is one thing, challenging the world food system is another. For this to happen, the glocal garden would have to make a significant contribution 
to world food security. It is beyond the scope of this paper to quantify what significant would mean, but clearly it would be more than a small niche.

There are various reasons to question a significant UA contribution to meet the worldwide demand for fruits and vegetables. It can be argued that there will not be sufficient physical space in urban areas to get the amount of (sustainable) produce needed to feed the urban people. This argument can be supported by observations related to the available space in urban areas worldwide today, which has been estimated at one third of the total global urban area [63]. This estimate does not take into account the number of local circumstances that would in practice prevent UA projects to take off, including ownership, urban planning, soil conditions etc. The glocal garden would have to resist the global urbanization trend, demanding more land for developing settlements, industry, and infrastructure. Also from a sustainability perspective a significant contribution from UA is not evident. In mainstream thinking, 'biological' or 'organic' farming produces less than conventional farming. With these sustainable farming methods, feeding an increasing world population would require even more land, which would further diminish rainforest and other valuable ecosystems on the planet. From a sustainability point of view this would be unacceptable. Instead, even if UA could make a contribution, sustainable farming would imply producing more with less land and less people.

Several observations refute mainstream thinking. First, the physical space practically available over time is far from static, which is, ironically, due to the global urbanization trend itself. Turning more rural agricultural land and nature into metropolitan urban areas will at the same time create 'empty' spaces where green projects can flourish. Second, the trend towards urbanization triggers more demand for urban green. The UN and several member states have already defined standards, as not yet legally binding, for the amount of green space per urban inhabitant [64]. Considerations related to health and labor productivity provide an incentive for companies, citizens and urban planners to allocate more green space. Third, where in the 20th century (urban) planning was still dominated by the idea of competition and separation between functions, including agriculture and nature, or agriculture and recreation, today's mood is more towards integration, creating a so-called win-win. If rural agriculture would be sustainable in that the quality of the soil and its ecosystems are preserved, there is much less need to decrease the share of agricultural land. The same is true for UA, which potentially combines many positive functions of urban green. Hence, sustainability requirements in metropolitan areas will encourage that more urban space will be allocated for gardening, not only on land but also on rooftops, along walls etc. This will considerably increase (peri)urban landscape quality. It is however obvious that the (re)conquering of green space will not go without heavy political conflicts. The glocal garden stands a chance to overcome, if it is based on community involvement and ownership and if it adds economic value to the local area.

A fourth observation is that UA has always been and still is quite significant in volume. World War I and II witnessed a peoples' movement, largely stimulated by the respective governments, to maintain so-called Victory Gardens in Canada, United Kingdom, United States, Australia and other countries [65-67]. The production of food was vital for winning the war. People used their back-yards but also public places to produce vegetables and fruits. The US Department of Agriculture estimated that more than 20 million victory gardens were planted. By 1944, fruit and vegetables harvested in these home and community plots was estimated to be 9-10 million tons, an amount equal to all commercial production of fresh vegetables in the USA.

Today, some estimates say that $15-20 \%$ of the world's food is already grown in urban areas [68]. Especially in poor metropolitan areas in Bangladesh, Vietnam, Nepal, Malawi and Guatemala between $40 \%$ and $80 \%$ of the population is participating in UA activities [69]. In Japan, almost one-third of all agricultural output in the country is generated by UA. Urban farmers account for $25 \%$ of farming households in Japan [57]. Even if the figures on the actual share of UA to the world supply of vegetables and fruits proved incorrect, the actual number of initiatives worldwide is impressive.

If the local gardens together would indeed be able to increase their production in that it would be significant enough to challenge the global food regime, there is still one element to be added in order to become a global project. Glocal gardens could really become global in character if they would start working together. Cooperation could take place at a bilateral or multilateral level, in informal networks sharing knowledge and skills. Cooperatives could constitute a lobby for political attention and for mutual support in their struggles with local developers and policy planners. They could help each other with loans for investments. Perhaps cooperatives in the North and the South could increase their attractiveness vis-à-vis their membership, joining forces and trading products that certain cooperatives cannot grow themselves given climate conditions. There are many examples of fruits and vegetables that can ripen during long distance transportation by ship, which is not necessarily unsustainable. Such collaboration may bring additional financial benefits and would strengthen cooperatives' competitiveness vis-à-vis the retail sector. Other forms of collaboration could be considered as well, such as sustainable tourism. Small-scale agriculture projects do not need expensive certification systems to convince their supporters with respect to the sustainability of the partner far away, there are sufficient online communication techniques to keep informed in a transparent manner. UA cooperatives may further be tempted to seek collaboration with SMEs in different sectors of rural agriculture. At this point, when (in)formal collaboration is established, institutions emerge with the potential of challenging the global food system.

\section{Conclusions}

This paper has set out to explore the conditions needed for UA to make a difference in accelerating a sustainability tran- 
sition of the global food system, taking into account interests of urban farming in both the North and the South. Obviously, there are currently many views on the physical potential of UA within the food system as well as the drivers and motives for people engaging in urban farming initiatives. There are also critical assessments with respect to the sustainability of UA. In developing the notion of a glocal garden, which can trigger an acceleration of a food system transition, this paper takes stock from some of these, neglecting others. In that sense, this paper is biased toward possible trajectories for a food system sustainability transition. The conditions discussed relate to innovations at the intersection of sectors and fields that are currently still considered separately.

For the glocal garden as an environmental project, the paper discussed innovations in the knowledge system where new linkages are developed for food-energywater-soil and waste. Environmentally sound innovations contribute to financial stability of the glocal garden. For addressing the vulnerability of the glocal garden as a social project, the social innovation proposed is the consumer cooperative that provides its membership with selective benefits, including financial gain. The glocal garden as an economic project will benefit from innovations that enable intensive farming, striving for the highest yield in a sustainable manner. As a global project, UA already makes a considerable contribution to the worldwide demand for vegetables and fruits. Given autonomous developments, including the global trend towards urbanization, an even greater share can be foreseen for the near future. Collaboration between cooperatives around the globe, between the North and the South in particular, as well as developing (new) forms of collaboration with rural agriculture will be a necessary and decisive step in accelerating the transition.

This paper does not at all deny or ignore the variety of interests, motives and concerns that underlie decisions by millions of people, each day, to participate in UA projects worldwide. It also recognizes the importance of a pluralist approach that enables people to take their share. Interestingly, however, a system's transition is in the end not only

\section{References and Notes}

[1] Fresco L. We need to feed the whole world; 2009. Available from: http://www.ted.com/talks/louise_fresco_on_feeding_the_whole_world.

[2] Rabbinge R. Bevolkingsgroei en wereldvoedselvoorziening. Chemisch Magazine. 1995;427-430.

[3] World Population to 2300. United Nations Organization, Department of Economic and Social Affairs/Population Division 1; 2003. Available from: www.unpopulation.org.

[4] Over the last 100 years world population has increased five times, but food production has increased more with a decreasing number of farmers [2]. Whereas in the Middle Ages one hectare could produce $1000 \mathrm{~kg}$ of grains, by the start of the $21 \mathrm{st}$ century the farmers in North Western Europe were able to produce $8000 \mathrm{~kg}$ wheat per ha with much less labor than ever before. This increase is considered possible for many parts of the world. Currently, the EU uses 127 million hectare for the production of food crops. Basically, a more efficient agriculture would have to exploit at most 92 million hectare and as a minimum about 30 million to keep on track with current food demand (Dutch dependent on individual drivers. Instead, the awareness of participants is shaped by the many (contradictory) tendencies today, some of which work in the advantage of the here presented view, whereas others do not. There is a growing dissatisfaction with neoliberal practices, large scale production and the interminable gap between investors, producers and consumers. There is an increasing interest in sustainability, in good and healthy food, locally produced, as well as in diversification including varieties of so-called 'forgotten' vegetables. More importantly, however, for an increasing part of the world the major concern is (still) fresh food availability. There is obviously no guarantee what the (virtual) end point of a transition in the food system will be. It is very well possible that an emerging food regime will, in terms of quality standards and products, split societies into the haves and the have-nots. Yet, what makes the glocal garden so interesting to explore from a system perspective, is exactly that it has the potential of countering such development. After all, gardening is traditionally for people from all social, ethnic and cultural backgrounds.

From the perspective of governance, too, the glocal garden is an interesting case. This is because, in contrast to the energy transition in many countries, UA is an issue primarily dealt with at local level. The glocal garden will face both resistance and opportunities that it must deal with by confronting local policy-makers and urban planners. Without doubt, the interests of land owners, developers and builders transcend in many cases local community and municipality borders, which makes them powerful as well as vulnerable. Instead, small local groups have an advantage in successfully promoting their interests, which is favorable for the glocal garden.

\section{Acknowledgements}

The author would like to thank Nicolien van der Grijp and two anonymous reviewers for their valuable comments and suggestions.
Scientific Council for Government Policy, cited in [2], p. 31).

[5] Fresco LO. Challenges for food system adaptation today and tomorrow. Environmental Science \& Policy. 2009;12(4):378-385. doi:10.1016/j.envsci.2008.11.001.

[6] Report of the Committee on Food Security. Rome, Italy: Food and Agriculture Organization of the United Nations; 2007. 30th session.

[7] Draper C, Freedman D. Review and analysis of the benefits, purposes, and motivations associated with community gardening in the United States. Journal of Community Practice. 2010;18(4):458-492. doi:10.1080/10705422.2010.519682.

[8] Wunder S. Learning for sustainable agriculture: Urban gardening in Berlin. Berlin, Germany: Solinsa and Ecologic; 2013. Available from: http://ecologic.eu/10308.

[9] Scheromm P. Motivations and practices of gardeners in urban collective gardens: The case of Montpellier. Urban Forestry \& Urban Greening. 2015;14(3):735-742. doi:10.1016/j.ufug.2015.02.007.

[10] Veen EJ. Community gardens in urban areas: A critical reflection on the extent to which they strenghten social cohesion and provide alternative food [PhD Thesis]. Wageningen University. Wageningen, 
Netherlands; 2015. Available from: http://library.wur.nl/WebQuery/ wda/2092742.

[11] Urban Agriculture. Food and Agriculture Organization of the United Nations. Available from: http://www.fao.org/urban-agriculture/en/.

[12] Goldstein B, Hauschild M, Fernández J, Birkved M. Urban versus conventional agriculture, taxonomy of resource profiles: A review. Agronomy for Sustainable Development. 2016;36(1):1-19. doi:10.1007/s13593-015-0348-4.

[13] Simatele DM, Binns T. Motivation and Marginalization in African Urban Agriculture: The Case of Lusaka, Zambia. Urban Forum. 2008;19(1):1-21. 10.1007/s12132-008-9021-1.

[14] USDA Defines Food Deserts. Nutrition Digest;35(3). Available from: http://americannutritionassociation.org/newsletter/usdadefines-food-deserts.

[15] Hisschemoller M. Local energy initiatives cannot make a difference, unless.... Journal of Integrative Environmental Sciences. 2012;9(3):123-129. doi:10.1080/1943815x.2012.716193.

[16] Rotmans J, Kemp R, van Asselt M. More evolution than revolution: transition management in public policy. Foresight. 2001;3(1):15-31. doi:10.1108/14636680110803003.

[17] Martens P, Rotmans J. Transitions in a globalising world. Futures. 2005;37(10):1133-1144. doi:10.1016/j.futures.2005.02.010.

[18] Grin J, Rotmans J, Schot J. Transitions to sustainable development: new directions in the study of long term transformative change. New York, NY, USA: Routledge; 2010.

[19] Loorbach D. Transition management: new mode of governance for sustainable development. Dublin, Ireland: International Books; 2007. Available from: http://hdl.handle.net/1765/10200.

[20] Loorbach D. Transition management for sustainable development: a prescriptive, complexity-based governance framework. Governance. 2010;23(1):161-183. doi:10.1111/j.1468-0491.2009.01471.x.

[21] Loorbach D, Van Der Brugge R, Taanman M. Governance in the energy transition: Practice of transition management in the Netherlands. International Journal of Environmental Technology and Management. 2008;9(2-3):294-315. doi:10.1504/ijetm.2008.019039.

[22] Friedmann H. From Colonialism to Green Capitalism: Social Movements and Emergence of Food Regimes. In: New Directions in the Sociology of Global Development. Bingley, UK: Emerald. pp. 227-264. doi:10.1016/s1057-1922(05)11009-9.

[23] Lang T, Heasman M. Food wars: The global battle for mouths, minds and markets. New York, NY, USA: Routledge; 2015.

[24] Jasanoff S. Civilization and madness: The great BSE scare of 1996. In: Hisschemöller M, Hoppe R, Dunn WN, Ravetz JR, editors. Knowledge, power, and participation in environmental policy analysis. vol. Vol. 12 of Policy Studies Review Annual. Transaction Publishers; 2001. pp. 251-270.

[25] Proka A, Hisschemöller M, Loorbach D. From business model innovation to energy system transformation: Towards a framework for the analysis of energy niches. submitted to Research Policy on 22 March 222016.

[26] Mancebo F. It's not only city design-We need to integrate sustainability across the rural-urban continuum. The Nature of the Cities. 2014 Mar 24; Available from: http://www.thenatureofcities.com/2014/03/24/its-not-only-onlycity-design-we-need-to-integrate-sustainability-across-the-ruralurban-continuum/.

[27] Greenhouse Village, the Greenhouse powered neighbourhood. Innovation Network. 2007; Available from: www.transitiepraktijk.nl/files/ flyer_greenhouse_village.pdf.

[28] Bareau—Duurzame Technologie; Available from: http://www.bareau.nl/.

[29] Hisschemöller M, Bode R. Institutionalized knowledge conflict in assessing the possible contributions of $\mathrm{H} 2$ to a sustainable energy system for the Netherlands. International Journal of Hydrogen Energy. 2011;36(1):14-24. doi:10.1016/j.ijhydene.2010.09.024.

[30] Origin of Biochar-Terra Preta. BIOCHAR.info. Available from: www.biochar.info/biochar.terra-preta.cfml;terrapretamain.html.

[31] Sohi SP. Carbon Storage with Benefits. Science. 2012;338(6110):1034-1035. 10.1126/science.1225987.

[32] Oben EE. The potential of carbon capture and storage (CCS) in Mabeta Kombo, Cameroon, using the 4P+ concept [MSc Thesis]. VU University of Amsterdam. Amsterdam, Netherlands; 2011.

[33] Fairchar. Available from: www.fairchar.com.
[34] See in this respect also the case study by Gieryn (1999) into how scientist Albert Howard through on site observation of agricultural practices in former British colonies discovered the relevance of practical knowledge and became a founding father of integrated agriculture. Gieryn TF. Cultural boundaries of science. Chicago, IL, USA: University of Chicago Press; 1999.

[35] The Tragedy of the Commons. Science. 1968;162(3859):1243-1248. doi:10.1126/science.162.3859.1243

[36] Olson M. The logic of collective action: Public goods and the theory of groups. 1965.

[37] Ostrom E. A Behavioral Approach to the Rational Choice Theory of Collective Action: Presidential Address, American Political Science Association, 1997. The American Political Science Review. 1998 mar;92(1):1. doi:10.2307/2585925.

[38] O'hare M. "Not On My Block You Don't"-Facilities Siting and the Strategic Importance of Compensation. Cambridge, MA, USA: Massachusetts Institute of Technology, Laboratory of Architecture and Planning; 1977.

[39] Hisschemöller M, Midden CJH. Technological risk, policy theories and public perception in connection with the siting of hazardous facilities. In: Vlek C, Cvetkovich G, editors. Social Decision Methodology for Technological Projects. Springer; 1989. pp. 173-194.

[40] Except in cases with large social or ethnic (racial) inequality..

[41] Simon HA, Luce RD, Raiffa H. Games and Decisions: Introduction and Critical Survey. American Sociological Review. 1958;23(3):342. doi:10.2307/2089260.

[42] Jenkins JC. Resource Mobilization Theory and the Study of Social Movements. Annual Review Sociology. 1983;9(1):527-553. doi:10.1146/annurev.so.09.080183.002523.

[43] Seyfang G, Smith A. Grassroots innovations for sustainable development: Towards a new research and policy agenda. Environmental Politics. 2007;16(4):584-603. doi:10.1080/09644010701419121.

[44] Barendse HFJ. The conditions for a successful introduction of the auction system in horticulture. Acta Horticulturae. 1988;223(X International Symposium on Horticultural Economics):17-23. doi:10.17660/actahortic.1988.223.1.

[45] Meulenberg MTG. Horticultural Auctions in the Netherlands. Journal of International Food \& Agribusiness Marketing. 1990;1(3-4):139165. doi:10.1300/j047v01n03_08.

[46] Tourte L, Gaskell M. Horticultural auction markets: Linking small farms with consumer demand. Renewable Agriculture and Food Systems. 2004;19(03):129-134. doi:10.1079/raf200475.

[47] Ter Hofstede P. De ontwikkeling van de fruitveilingen. In: Vijftig jaar Nederlandse fruitteelt. Amsterdam, Nederlands: Uitg. voor de Nederlandse Fruittelers Organisatie door Uitg. Agrarisch Fonds Amsterdam; 1948. pp. 133-158.

[48] Gibbs JP. Foundations of Social Theory. By James S. Coleman. Harvard University Press, 1990. 993 pp. $\$ 39.50$. Social Forces. 1990;69(2):625-633. doi:10.1093/sf/69.2.625.

[49] Snijders C. Book Review Trust in Modern Societies: The Search for the Bases of Social Order. By Barbara A. Misztal. Cambridge, MA, USA: Polity Press, 1996. pp. 296. American Journal of Sociology. 1997;102(6):1724-1725. doi:10.1086/231133.

[50] McCaughrin C. Book Reviews : The Formation of National States in Western Europe. Edited by Charles Tilly. (Princeton: Princetom University Press, 1975. pp. 638). Political Research Quarterly. 1976;29(2):324-325. doi:10.1177/106591297602900228.

[51] Hisschemöller M, Sioziou I. Boundary organisations for resource mobilisation: enhancing citizens' involvement in the Dutch energy transition. Environmental Politics. 2013;22(5):792-810. doi:10.1080/09644016.2013.775724.

[52] Boons F, Lüdeke-Freund F. Business models for sustainable innovation: state-of-the-art and steps towards a research agenda. Journal of Cleaner Production. 2013;45:9-19. doi:10.1016/j.jclepro.2012.07.007.

[53] Yunus M, Moingeon B, Lehmann-Ortega L. Building Social Business Models: Lessons from the Grameen Experience. Long Range Planning. 2010;43(2-3):308-325. doi:10.1016/j.Irp.2009.12.005.

[54] Noll Rv, Baarsma B, Rosenboom N, et al. Van teelt tot schap: Waardecreatie door de groothandel in groenten en fruit. Amsterdam, Netherlands: SEO; 2010.

[55] von Kreyfelt MJA. Boeren Hans Huijbers: Voedselsys- 
teem aan rand van failliet. Foodlog. 2016 Jun 1; Available from: http://www.foodlog.nl/artikel/boerenleider-hans-huijbersvoedselsysteem-aan-rand-van-failliet/.

[56] Fighting Poverty and Hunger. Food and Agriculture Organization of the United Nations; 2010. Policy Brief 10. Available from: http://www.fao.org/docrep/012/al377e/al377e00.pdf.

[57] Moreno-Peñaranda R. Japan's Urban Agriculture: Cultivating Sustainability and Well-being. United Nations University. 2011 Sept 20; Available from: http://unu.edu/publications/articles/japan-s-urbanagriculture-what-does-the-future-hold.html.

[58] Garnett T. Urban agriculture in London: rethinking our food economy. In: Growing Cities, Growing Food. Feldafing, Germany: German Foundation for International Development; 2000. pp. 477-500.

[59] Bellows AC, Brown K, Smit J, et al. Health benefits of urban agriculture. Community Food. 2003; Available from: http://foodsecurity.org.

[60] Royte E. Urban farming is booming, but what does it really yield? Ensia. 2015 Apr 27; Available from: http://ensia.com/features/urbanagriculture-is-booming-but-what-does-it-really-yield/.

[61] Fortier JM, Bilodeau M. The Market Gardener: A Successful Grower's Handbook for Small-scale Organic Farming. Vancouver, Canada: New Society Publishers; 2014.

[62] Small and medium-sized enterprises and decent and productive employment creation. Geneva, Switzerland: International Labor Office; 2015. Report IV. Available from: http://www.ilo.org/wcmsp5/groups/public/@ed_norm/@relconf/ documents/meetingdocument/wcms_358294.pdf.

[63] Martellozzo F, Landry JS, Plouffe D, Seufert V, Rowhani P, Ramankutty N. Urban agriculture: a global analysis of the space constraint to meet urban vegetable demand. Environmental Research Letters. 2014;9(6):064025. doi:10.1088/1748-9326/9/6/064025.

[64] Roo M. The Green City Guidelines-Techniques for a healthy liveable city. Available from: http://aiph.org/wp-content/uploads/2015/04/ Green\%20City\%20-\%20Guidelines.pdf

[65] Hayden-Smith R. Sowing the Seeds of Victory: American Gardening Programs of World War I. Jefferson, NC, USA: McFarland; 2014.

[66] Farming in the 1940s. Living History Farm. Available from: http: //www.livinghistoryfarm.org/farminginthe40s/crops_02.html.

[67] Victory Garden. Wikipedia. Available from: https://en.wikipedia.org/ wiki/Victory_garden.

[68] Karanja N, Njenga M. Chapter 10. Feeding the Cities. In State of the World. Nourishing the Planet; 2011. Available from: http://blogs.worldwatch.org/nourishingtheplanet/wp-content/ uploads/2011/02/Chapter-10-Policy-Brief_new.pdf?cda6c1.

[69] Urban Agriculture and Urban Security-Some Figures and Facts Food and Agriculture Organization of the United Nations; Available from: http://www.fao.org/economic/es-policybriefs/multimedia0/ presentation-urban-agriculture-and-food-security/en. 